\title{
Spending and development in Papua province of Indonesia
}

\author{
Thobby Wakarmamu ${ }^{a^{*}}$ and Yohanes Indrayono ${ }^{b}$
}

${ }^{a}$ Lecturer at Economic Faculty, Cendrawasih University, Jayapura, Papua, Indonesia

${ }^{b}$ Lecturer at Post Graduate of Management Program, Univeritas Pakuan, Bogor, Indonesia

\section{CH R O N I C L E}

\section{Article history:}

Received: May 15, 2019

Received in revised format: June

222019

Accepted: June 23, 2019

Available online:

June 23, 2019

Keywords:

Regional expenditure allocation

Gross Regional Domestic Product

Human Development Index

Papua

\section{A B S T R A C T}

Regional autonomy is designed to increase the welfare of the community with the idea that regional government best understands what must be done in order to increase and improve human resources. The quality of human resources in a community can be a determining factor for the success of development initiatives in a region. Regional governments must be able to properly plan, to implement, and to evaluate regional budget allocations as they have direct impacts on regional gross regional domestic product (GRDP) as well as on measurable community welfare as measured by the Human Development Index (HDI). This study examines the relationship between government spending and human development in regional governments of Papua Province, Indonesia as measured by the HDI. A secondary analysis of government data and Human Development Index (HDI) data was conducted using structural equation modelling. The secondary analysis of regional government budget allocations and HDI data suggests that spending with the goal of improving the lives of community members seems to lead to an improvement of HDI. This study is focused on regional governments in one province of Indonesia. While its findings suggest that governments should make supporting human resources a priority if they hope to see improvement in HDI, similar studies should be conducted in other communities in order to see how different cultural or political settings affect the relationship between spending and HDI. This study adds to our understanding of development with its focus on Papua Province, an under-studied area in development research.

\section{Introduction}

Human development is at the heart of development planning as the essence of development is to improve the people' lives. It is imperative that human development needs to be prioritized for the planning of budget expenditures (Fhino \& dan Priyo, 2009; Bhakti et al., 2018). Spending on human development could lead to an improvement in the welfare of the broader community as measured by the Human Development Index (HDI). Currently, development is most often linked to economic growth since it can contribute to the quality of life. Since 1999, the United Nations Development Program (UNDP) has been working to develop the HDI, seeking to understand the quality of individuals' lives around the world (Amalia \& dan Purbadharmaja, 2014). The HDI takes a three-dimensional approach to the measurement of quality of life. These dimensions include longevity and health, knowledge, and a decent life. The main * Corresponding author.

E-mail address: yindrayono@gmail.com (Y. Indrayono) 
objective of this study is to explore how regional government spending in the Papua Province of Indonesia affects its performance on the HDI.

The rest of this paper is organized into 7 sections. Section 2 provides a background for regional autonomy and human development index. Section 3 introduces the applied fiscal policy in Indonesia with emphasis on the role of capital expenditure, and local expenditure. The theoretical framework of Agency Theory is addressed in section 4 . The next section states the research hypotheses and questions to be addressed. Section 5 elaborates on the methodology. Section 6 views results and discusses the main findings with reference to the relevant studies in the literature.

\section{Regional Autonomy and Human Development Index}

The main objective of regional autonomy is to improve the welfare of the community and, to do so, governments must increasingly invest in human resources. A healthy, productive, educated population can have a big impact on the development in a region. The development paradigm places humans (residents) at the center and the ultimate goal of all development activities, namely achieving mastery over resources, improving health, and improving education is the improvement of resident well-being. An increase in human development in a region is often reflected in a region's performance on the HDI.

When we examine the performance of autonomous regions in Indonesia, success can be marked by an increase of services and social welfare, an increase in advanced democratic life, and a sense of justice and equality. Good relations between the central government and the regional government, as well as between other regions, is also a marker of the successful administration of an autonomous region. This view is in line with the direction of authority that covers all fields of government in the framework of regional autonomy (Gozali et al., 2001). One of the most powerful tools a government has in regard to autonomy and development is its ability to allocate resources; for instance governments decide how much can be spent on things such as education, health, irrigation, and transportation (Sasana, 2009) which directly impact the lives of citizens as well as the development of communities. Such public sector spending is closely connected to human development (Astri, 2013).

Economic growth is an indicator of regional economic performance. Economic growth is an increase in aggregate output (overall goods and services produced by economic activities) or Gross Regional Domestic Product (GRDP). GRDP itself is the total value of all final output produced by a regional economy, carried out by both local residents as well as foreigners living in the country. A common measure that is often used to understand the economic growth rate is the percentage change in GRDP for the nation compared with the percentage change in GRDP for the province, city, or district.

A relatively high level of human development will affect economic growth by improving population capabilities, which is likely to result in increased productivity and creativity of the community. With the increase in productivity and creativity, communities can absorb and manage resources that are important for economic growth (Brata, 2004). The influence of human development on economic growth through the improvement of the quality of human resources is commonly called the quality of human capital (Ranis \& Stewart, 2002). The concept of the quality of human capital refers to a commodity that can be produced and accumulated, and the cost of producing quality of human capital can often be paid for with future economic returns (Ananta, 1986). Improving the quality of human capital can be achieved by focusing on two determinants that are often mentioned in the literature: education and health.

Lerner (1958) described a developing society as the one which embraces new technologies which facilitate economic and social growth. Such embrace of technology is not always linear, with Rogers (1995) suggesting that, as technologies diffuse through a society, they are not neatly and uniformly adopted by the target group. Assuming they are linearly adopted can lead to the failure of development projects (Rogers, 1995). According to Myrdal (1974), "development is the movement upward of the entire social system" (p. 729) of a place. This includes economic and non-economic factors as well as the way of the individuals living in a community (Myrdal, 1974). However, development has, at times, been more focused on the resources of a place rather than the people who live there (Arndt, 1981). Development projects are often designed around established industries which could spur economic growth (Johnston 
$\&$ Mellor, 1961) or they are focused on the environmental rehabilitation of a particular area (Feoli et al., 2002). Whether focused on resources, environment, or technology, development projects are generally created with the goal of improving the people living in the target communities. Expenditures in the health sector are expected to increase life expectancy and to reduce maternal and infant mortality as a component of human development (Sahrah, 2007). Budget allocations for education will increase the community's access to a better and cheaper education and, therefore, help increase literacy in the community (Musgrave, 1956). Spending on infrastructure can improve a community's ability to participate in the workforce, as well as participate in the marketplace, which increases real per capita consumption (Delavallade, 2006). Looking at the allocation of government expenditures on public goods, a high percentage of that spending remains earmarked for routine services rather than for development projects at both the national and regional level (Suparto, 2005; Marmot, 2005). The human development paradigm has four economic pillars which contain the following principles: productivity, equity, sustainability, and empowerment (Bappenas, 2001). The Human Development Index (HDI) is based on three categories: (1) longevity reflected in the life expectancy index; (2) educational attainment measured by the combination of literacy rates and the average length of the school period; (3) the standard of living as measured by consumer spending per capita in rupiah. The HDI scale is between 1 and 100 .

According to the United Nations Development Program (UNDP), human development is defined as a process of elaborating choices for residents. The focus of development is the people themselves because they are the real wealth of a nation. Human quality development is considered as planned efforts to increase the individuals' capacities and communities of a nation to be able to actively determine their future in order to achieve material and spiritual prosperity. According to Widodo et al. (2011), human development is an indicator of progress of a country. A country is considered to be advanced not only based on its gross domestic income but also based on the life expectancy and education of its people. According to Badan Pusat Statistik (2015), the term human development was first popularized by the UNDP in 1999 and is periodically discussed in the annual Human Development Report (HDR).

The Human Development Index (HDI) measures human development outcomes based on a number of basic components of quality of life. As a measure of quality of life, HDI is built based on a three-dimensional approach, which includes longevity and health, knowledge, and a decent life. To measure the health dimension, life expectancy at birth is used. To measure the dimension of knowledge, a combination of indicators of school-age expectations and the average length of school are used. To measure the dimension of decent life, people's purchasing power over a number of basic needs is examined, with the average amount of spending per capita as one way of understanding how a community is doing in regards to the development of a decent life. The HDI approach can be used for planning the development of human resources since it is associated with health, education, and overall welfare.

\section{Fiscal Policy in Indonesia}

Government spending is a part of fiscal policy (Sukirno, 2000) which allows a government to manage the economic sector by determining income and outcome per year, as reflected in Indonesia in the state budget for national budgeting and regional budget for regional budgeting. The purpose of this fiscal policy is to stabilize prices, output levels, and employment opportunities, and to support economic growth. According to Baswir (1999) quoted by Sinulingga (2008), in general, a government budget can be interpreted as a financial plan that reflects the policy choices of an administration for a period of time in the future. A government makes visible its priorities through its allocation of resources in a budget.

Based on the current budget structure, the local government budget is called the selected budget. The government budget structure, in the budget system in Indonesia, recognizes two types of government expenditure: routine expenditure and development expenditure. Routine expenditure is the spending to ensure the functioning of government as it includes things such as payment of employee salaries. Development expenditure is spending categorized as government investment, including investment in education and health (public) sectors. 
Government spending in the health sector is an effort to fulfill one of the basic rights of the people, namely the right to obtain health services in accordance with the 1945 Constitution, Article $28 \mathrm{H}$ Verse (1) and Law Number 23 of 1992 concerning health. The constitution states that health is a basic human right, so the government is responsible for ensuring the protection and health of its people. Additionally, the national development goals state that every resident has the right to obtain the highest degree of health. Thus, government investment in health can be seen as investment in human resource development.

\subsection{Capital Expenditure}

Performance is the achievement/realization of what has been planned. The performance of a person or organization is said to be good if the results achieved are in accordance with the planned targets. Performance is said to be very good if achievement exceeds the target. Performance is said to be bad if achievement is lower than the target (Sularso \& Restianto, 2011). One way of judging the performance of a government as it relates to development is by examining its capital expenditures. Capital expenditures are associated with output and are generally used to add fixed assets/useful inventory for more than one accounting period, including costs for maintaining facilities or infrastructures over a period of time or costs which can increase asset capacity and quality. Halim (2007) divides capital expenditure into two parts. The first, public expenditure, is spending which directly benefits the general public. Examples of public expenditure include the construction of bridges and highways, the purchase of mass transportation equipment, and the purchase of ambulances. The second part of capital expenditure is the expenditure for apparatus. In this case, the spending is focused on things which may not directly be enjoyed by the public, but are felt directly by the apparatus of government, such as the purchase of official vehicles, construction of government buildings, and construction of official residences. A higher level of capital investment is expected to improve public services, which are expected to improve community welfare as measured by the HDI. A contingency approach will be used in this study to examine whether there is a relationship between regional fiscal performance and HDI. Based on past research, there is an expectation that capital expenditures will affect the HDI.

\subsection{Local Expenditure}

There is a responsibility of the regional governments to meet the development needs in their regions by optimizing local revenue sources in order to make improvements to the public sector. Todaro (2003) argues that there are three main components of economic growth (he was writing in the context of countries). The first one is capital accumulation, which includes all forms or types of new investment in land and physical equipment and human capital or human resources. The second one is population growth which will eventually lead to a growth of the workforce. Third, technological advances in the form of new techniques or improvements to old techniques of handling a job.

Todaro (2003) stated that capital accumulation occurs when a portion of income is saved and reinvested with the aim of increasing output and income in the future. According to Sasana $(2009,2016)$, the allocation of funds by local government for various development projects can aid in the building of public facilities and the improvement of infrastructure. In order for a region to improve and grow, a regional government must be willing to invest in local development projects. However, spending on projects is typically less highly prioritized than spending on employees, even though spending on such projects has benefits that can be directly felt by the community.

Population growth and labor force growth, which occurs several years after population growth, are traditionally considered positive factors that support economic growth. More laborers means a community is likely to have a higher number of productive workers. However, the supply of labor in developing countries has not been matched by the number of jobs so that the excess labor force does not necessarily have a positive impact on economic development. A skilled workforce is a potential human resource that is very much needed by countries seeking to participate in the global economy, but one that must be carefully managed and for which there must be jobs. Todaro (2003) states that investment in fostering 
human resources can also improve the quality of human capital, which, in turn leads to economic improvements. This is in accordance with human capital theory which suggests that education has an influence on economic growth because education plays a role in increasing labor productivity.

Government expenditures, then, are likely to play a significant role in the development of a community - be it a local, regional, or national one. This study is concerned with the role of regional governments in fostering the development of a community.

\section{Agency Theory}

Agency theory prescribes actions that focus on the protection of the investment of the principal against the harmful behaviors of the agent. Agency theory is useful in this context as one can approach the relationship between the community and the government as there may be a relationship between a principal and an agent. The agent is expected to make financial policy in favor of the principal. Principals have regulatory authority over the agent and provide resources to the agent in the form of taxes, levies, balancing funds, management of regional wealth, and other legitimate regional income (Jensen \& Meckling, 1976). In this instance, the community represented by the Gross Regional Domestic Product (GRDP) is the principal and the government is the agent. Regional governments must submit performance reports, especially in the area of regional finance, to assess whether the regional government has successfully carried out its duties properly or not. If the agent's decision is detrimental to the principal, there will be an agency problem. The agent does not know what is actually done (asymmetric information), so the principal needs a third party who is able to convince the principal that what is reported by the agent is true.

This research seeks to understand how capital expenditure allocations affect performance on the HDI through the lens of agency theory (Sandri et al., 2016; Jensen \& Meckling, 1976; Fox \&d Hamilton 1994; Nurmainah, 2013). The results of this study are expected to be useful to expand agency theory, especially in explaining conflicts between communities and the government regarding financial policies that may, or may not, improve the welfare of the community as measured by HDI. The results of this study are also expected to provide information to the regional government to help it determine what capital expenditures are most likely to lead to an improvement of the quality of public services. Agency theory is used as the main framework in this study to explain the conflicts that occur between the regional government and people represented by the GRDP, related to regional financial policies. These conflicts are often the result of the different interests and concerns of the two parties bound by the contract. For instance, the government does not only want to satisfy the principal of the contract, but also to maximize its interests. HDI is used as a measure of the success of development in an area over a certain time. Additionally, HDI is also a monitoring tool that can provide a comparison of the development in a region, or regions, over time so that one can understand the development carried out in a previous period (Badan Pusat Statistik, 2009).

\section{Research Hypotheses and Questions}

As mentioned earlier, HDI mainly targets health, education and life standards. Expenditures in the health sector are expected to increase life expectancy and to reduce maternal and infant mortality as a component of human development (Sahrah, 2007; Prasetyo, 2018). Budget allocations for education will increase the community's access to a better and cheaper education and, therefore, help increase literacy in the community. Spending on infrastructure can improve a community's ability to participate in the workforce, as well as to participate in the marketplace, which increases real per capita consumption (Delavallade, 2006). Therefore, the first hypothesis is postulated as follows.

H1. Capital expenditures (direct and indirect) influence HDI in Papua province.

The local government is expected to make financial policy in favor of the community represented by DPRD. However, the role of the community is not unsupervised and DPRD has regulatory authority over the local government and provides resources to the government in the form of taxes, levies, balancing funds, management of regional wealth, and other legitimate regional income (Hofman \& Guerra 2007; 
Jensen \& Meckling, 1976; Moreno-Enguix \& Bayona (2017); Prasetyo, 2018). Therefore, the financial resources offered by DPRD play a role in moderating the relation between capital expenditures and HDI.

H2. Financial resources provided by DPRD (special allocation funds and special autonomy funds) moderate the relation between capital expenditures and HDI.

Government spending is a part of fiscal policy (Sukirno, 2000) which allows a government to manage the economic sector by determining income and expenditures outcome per year. According to Baswir (1999), in general, a government budget can be interpreted as a financial plan that reflects the policy choices of an administration for a period of time in the future. A government makes visible its priorities through its allocation of resources in a budget. The fiscal policy is, thus, hypothesized to explain the relationship between capital expenditures and HDI. To elaborate, Cohen and Purcal (1989) have shown that, when it comes to the health of its workforce and citizens, Indonesia lags behind other ASEAN member countries. Singapore, Malaysia, Thailand, Brunei Darussalam, and even Vietnam have been placing a special emphasis on improving the health of their citizens through long-term human investment, while in Indonesia the government has not often prioritized health in its budget, which has hampered the improvement of Indonesia in regards to the HDI. Achsani et al. (2012) studied the impact of fiscal policy on the agricultural development in an emerging economy of the South Sulawesi in Indonesia. Consistent with Firman (2003) and Booth (2003), Achsani et al. (2012) emphasized the significance of Indonesia's fiscal decentralization reform.

H3. The fiscal policy of Indonesia/Papua province mediates the relationship between capital expenditures and HDI.

Fig. 1 represents the conceptual model of our study.

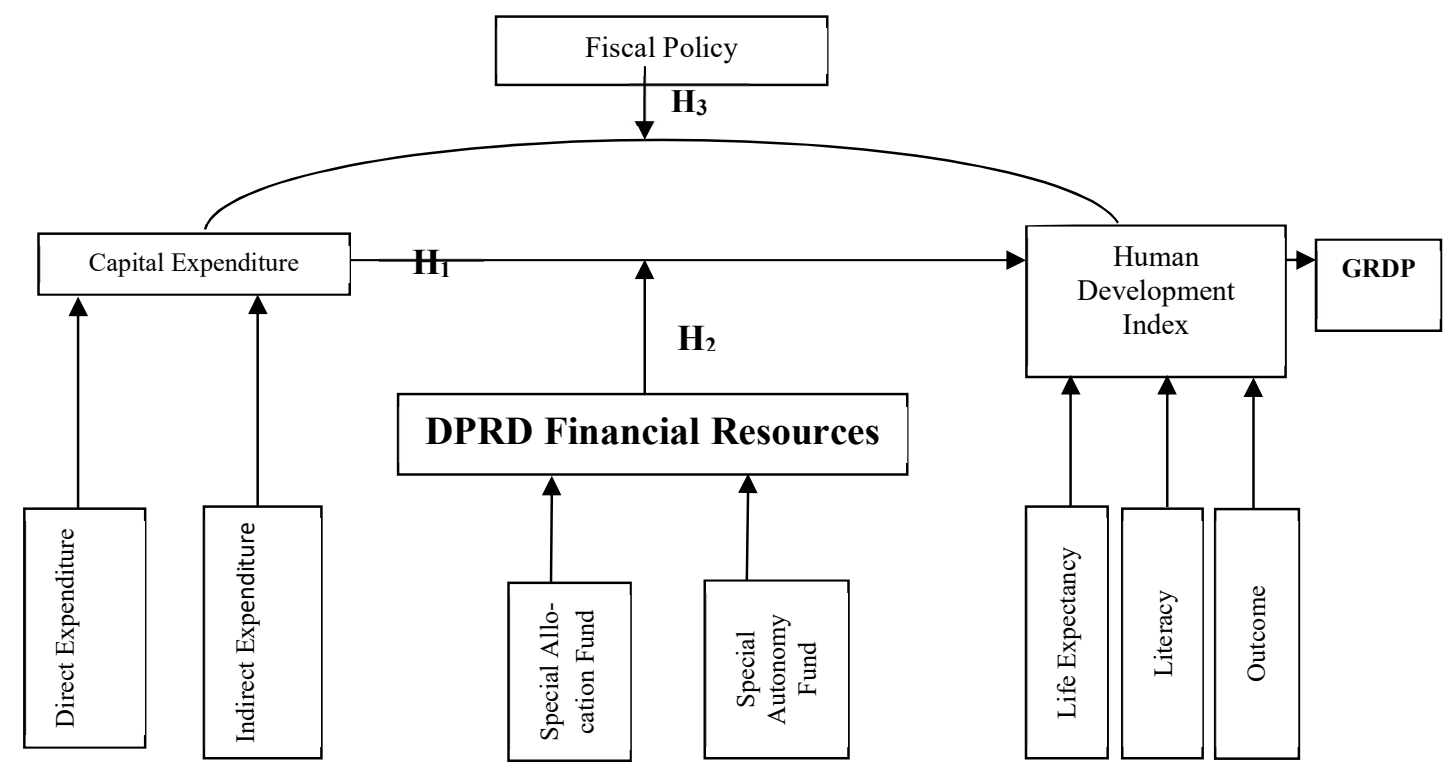

Fig. 1. Conceptual Model and Hypotheses

Thus, the following research questions are posed.

First, how can capital expenditure influence HDI in Papua province?

Second, can the local government financial resources provided by DPRD govern the capital expenditures and HDI? 
Third, how does the adopted fiscal policy of Indonesia/Papua province mediate the relationship between capital expenditures and HDI?

\section{Method}

The three hypotheses were approached quantitatively through the analysis of secondary data, including survey data, obtained from the Central Bureau of Statistics and the Ministry of Finance of the Republic of Indonesia. The data were analyzed using statistical methods to answer the questions and to test the research hypothesis. The sample examined included annual data for the period $2000-2016$. This data include the Gross Regional Domestic Product (GRDP) and Human Development Index (HDI) issued by Bank Indonesia, as well as data on regional expenditure allocation, Special Allocation Funds, and Special Autonomy Funds issued by the Ministry of Finance of the Republic of Indonesia.

There are two approaches for applying SEM: Covariance-based structural equation modeling (CB-SEM) approach and partial least squares structural equation modeling (PLS-SEM). The final phase of the analysis in this study is testing our hypotheses. Hypothesis testing was conducted using PLS-SEM because of the small sample size $(\mathrm{n}<200)$. Calculations were carried out with SmartPLS software version 3. Mapping the relationship between cities/districts in Papua Province based on the variables studied was conducted using multidimensional scaling (MDS). To that end, we used IBM SPSS statistical software (version 24; IBM Corp., Armonk, NY).

Applying a reflective measurement model, validation of this CB-SEM model can be verified by measuring its internal consistency, indicator reliability, convergent validity and discriminant validity. Internal consistency is usually calculated PLS-SEM by the measurement of composite reliability because it considers that items have different loadings. In this regards, measuring composite reliability is more accurate than measuring Cronbach's reliability although the latter is an accurate predictor of internal consistency. In PLS-SEM, sufficient convergent reliability is obtained when the average variance extracted (AVE) is greater than 0.5. Discriminant validity evaluates whether or not the analyzed indicators do measure different items. In PLS-SEM, Heterotrait-Monotrait ratio is considered a criterion value that has to be lesser than 0.85 . The other SEM sub-model, the structural model, readily affords the researcher flexibility in defining models with direct effects, indirect effects, reciprocal effects, and multiple outcomes. The test of the structural model will consist of path analysis (PA). The path coefficients from each latent factor to measured variables as well as error variances and covariance will not be constrained (Hair et al., 2016).

\section{Results and Discussion}

Data on the Human Development Index (HDI), Gross Regional Domestic Product (GRDP), and expenditure allocations obtained for the period 2000-2016 show an increase from year to year. There are twentynine cities and regencies in Papua Province, divided into five regions: La Pago, Ha Anim, Mee Pago, Saereri, and Mamta. La Pago includes Puncak Jaya, Yakuhino, Pegunungan Bintang, Tolikara, Nduga, Lanny Jaya, Mamberano Tengah, and Puncak regencies. Ha Anim includes Merauke, Boven Digoel, Mappi, and Asmat regencies. Mee Pago includes Mimika, Paniai, Dogiyai, and Deiyai regencies. Saereri includes Biak Numfor, Yapen Islands, Waropen, and Supiori regencies. Meanwhile, Mamta includes Jayapura, Sarmi, Keerom, and Jayapura city.

The yearly increase in HDI suggests positive development in regards to the welfare of the community in Papua Province. However, only twelve municipal districts have HDI values of more than 50. Seventeen other districts show room for improvement in regard to HDI and the welfare of the community. In 20152016, GDP reached Rp46.35 million to Rp48.30 million per year per capita. The GRDP is not high due to the high cost of living in Papua. Based on the preliminary data published by the Ministry of Finance, the total income of Papua in 2017 was Rp5.066 trillion and Rp3.136 trillion of that income, or around $61.9 \%$, was spent in the form of expenditure allocations. 
Table 1

Overview of Papua province's economic profile

\begin{tabular}{|c|c|c|c|c|c|c|c|c|c|c|}
\hline Year & Life Expectancy & Literacy & Outcome & HDI & $\begin{array}{c}\text { GRDP } \\
\text { (Million Rp) }\end{array}$ & Expenditure & $\begin{array}{c}\text { Indirect } \\
\text { Expenditure } \\
\text { (Million } \\
\text { Rp) }\end{array}$ & $\begin{array}{c}\text { Indirect } \\
\text { Employee } \\
\text { Expenditure } \\
\text { (Million } \\
\text { Rp) }\end{array}$ & $\begin{array}{l}\text { Special } \\
\text { Allocation } \\
\text { Funds } \\
\text { (Billion } \\
\text { Rp) }\end{array}$ & $\begin{array}{c}\text { Special } \\
\text { Autonomy } \\
\text { Funds } \\
\text { (Billion Rp) }\end{array}$ \\
\hline 2000 & 60.14 & 74.47 & 574.31 & 59.11 & 20.90 & (Million & 305.58 & 206.02 & 6.311 & 1058.807 \\
\hline 2001 & 60.25 & 74.57 & 575.74 & 59.69 & 24.56 & $2,243.10$ & 644.24 & 260.08 & 8.065 & 1199.306 \\
\hline 2002 & 60.90 & 74.50 & 578.20 & 60.10 & 23.09 & $2,536.23$ & 739.71 & 314.13 & 10.308 & 1358.449 \\
\hline 2003 & 61.20 & 74.35 & 581.00 & 60.83 & 25.72 & $2,625.75$ & $1,003.86$ & 368.19 & 13.175 & 1538.711 \\
\hline 2004 & 61.50 & 74.20 & 583.80 & 60.91 & 27.31 & $2,715.27$ & $1,474.97$ & 422.25 & 16.838 & 1742.892 \\
\hline 2005 & 61.90 & 74.90 & 585.20 & 62.10 & 28.90 & $3,509.31$ & $1,604.18$ & 476.31 & 21.521 & 1974.167 \\
\hline 2006 & 63.30 & 75.41 & 589.30 & 62.75 & 30.49 & $3,743.34$ & $1,757.56$ & 465.31 & 27.506 & 2236.131 \\
\hline 2007 & 63.60 & 75.41 & 593.42 & 63.41 & 32.07 & $3,917.75$ & $1,640.35$ & 571.48 & 28.900 & 2532.857 \\
\hline 2008 & 63.80 & 75.41 & 599.65 & 64.00 & 33.66 & $3,229.14$ & $2,963.63$ & 638.48 & 44.930 & 2868.958 \\
\hline 2009 & 64.05 & 75.58 & 603.88 & 64.53 & 35.25 & $4,331.05$ & $3,942.20$ & 826.16 & 81.270 & 4079.800 \\
\hline 2010 & 64.31 & 75.60 & 606.38 & 64.94 & 36.83 & $5,189.88$ & $4,130.89$ & 777.07 & 75.060 & 3494.860 \\
\hline 2011 & 64.46 & 75.81 & 609.18 & 65.36 & 37.11 & $5,541.15$ & $4,762.07$ & 866.79 & 72.120 & 3957.460 \\
\hline 2012 & 64.60 & 75.83 & 611.99 & 65.86 & 37.94 & $6,186.71$ & $5,816.09$ & 806.43 & 106.190 & 3833.400 \\
\hline 2013 & 64.76 & 75.92 & 616.76 & 66.25 & 40.51 & $7,125.27$ & $6,705.25$ & 833.44 & 133.900 & 4355.950 \\
\hline 2014 & 64.84 & 77.13 & 621.60 & 67.15 & 43.20 & $7,938.55$ & $6,783.51$ & 880.47 & 120.510 & 7122.110 \\
\hline 2015 & 65.09 & 77.87 & 626.90 & 67.72 & 48.30 & $11,205.08$ & $6,980.19$ & 919.02 & 460.300 & 7636.070 \\
\hline 2016 & 66.25 & 77.90 & 634.29 & 68.29 & 46.35 & $12,396.45$ & $11,968.49$ & $7,018.20$ & $1,222.56$ & 328.170 \\
\hline
\end{tabular}

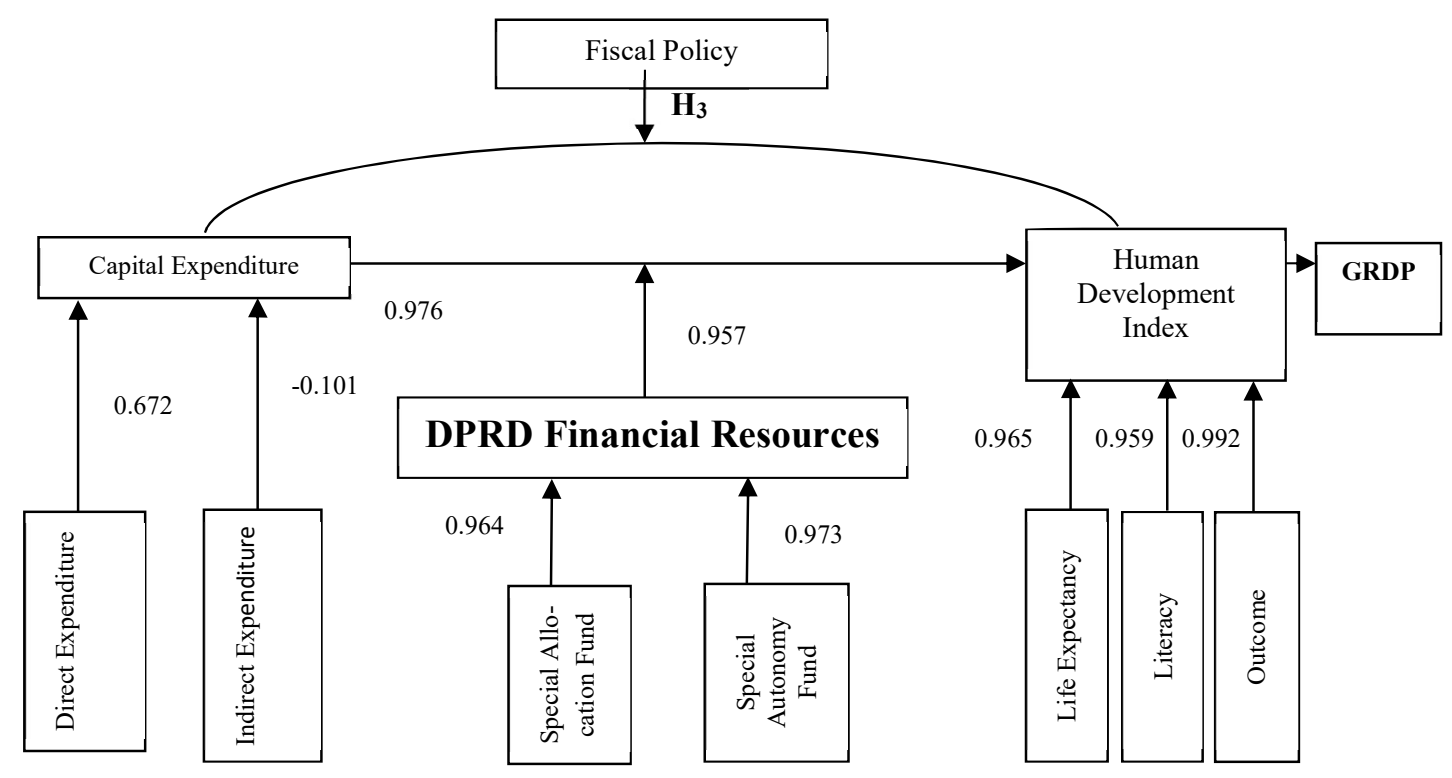

Fig. 2. The results of testing the hypotheses

The structural relationship between special funds in the form of Special Allocation Funds and Special Autonomy, Regional Expenditure Allocations, Gross Regional Domestic Products (GRDP), and HDI were analyzed by using SEM-PLS. The allocation for regional expenditure is largely determined by the amount of spending allocated for indirect expenditure and direct expenditure. In the path coefficient test results of the four variables, there are three significant relationships shown in the model. HDI is highly determined by the increase in GRDP. Meanwhile, changes in GDP depend on the amount of regional expenditure allocation. Increased expenditure allocation is determined by the amount of special allocation funds and special autonomy funds received by regional governments. The path coefficient of the special funds towards expenditure allocation, as much as 0.957 , is significant $(p<0.05)$. The path coefficient of expenditure allocation to GRDP, as much as 0.976 , is significant $(\mathrm{p}<0.05)$. However, the path coefficient of expenditure allocation to HDI, as much as 0.330 , is not significant ( $p>0.05)$. Meanwhile, the path coefficient of GRDP to HDI, as much as 0.665 , is significant $(\mathrm{p}<0.05)$. The result of this analysis shows that special funds and expenditure allocation have an indirect effect on the increase in HDI. The results are shown in Fig. 2. 
The result of the mapping of districts and cities in Papua based on regional expenditure allocation is shown in Fig. 3. The position of Puncak Regency appears to be quite far from other regions as its total expenditure allocation is the highest in Papua. At the same time, in regards to total regional income, Puncak Regency has less income than expenditure allocation. This condition certainly requires special attention so that the performance of the regional government can continue to improve. Based on financial reports issued by BPKAD of Papua, the total Papua special autonomy funds for the period 2002-2015 reached Rp52.636 trillion, with Rp10.117 trillion allocated to infrastructure funds.

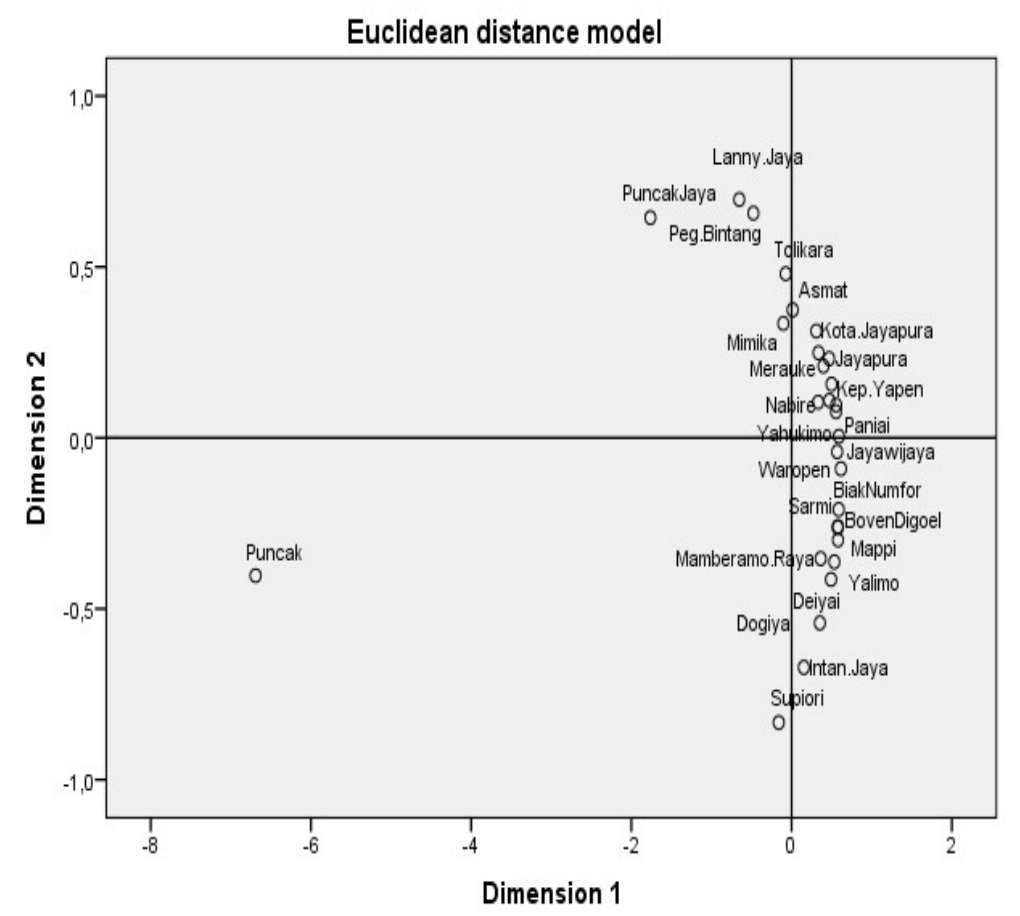

Fig. 3. Multidimensional Scaling of Expenditure Allocation

Regional autonomy gives regional governments the ability to decide how best to allocate funds in order to support regional development. Expenditure allocation by regional authorities in the era of autonomy is highly dependent upon the policies of the regional government and subject to legislative approval. The estimation results from the model used in this study show that regency/city government expenditure in Papua has a positive and significant influence on the Human Development Index. This positive influence implies that if governments in Papau increase their spending on things that will improve the broader community welfare, they are likely to see an increase in HDI. Of course, the opposite also seems to be true, that a decrease in spending on services that improve the lives of people will lead to a decrease in HDI. Current regional expenditure is divided into direct expenditure and indirect expenditure. Direct expenditure is used to improve the quality of public facilities and infrastructure or direct programs that can stimulate greater productivity in the community and for business actors in the region. In addition, regional government expenditure is also used for basic services that must be obtained by the community, namely education and health. With the right direct expenditure allocation, regional infrastructure and public facilities will continue to serve their communities, helping increase the quality and quantity of life, as well as regional productivity, community income, and performance on the HDI. Conceptually, indirect expenditure does not meet the needs of the general public, particularly as it pertains to running businesses. However, with the right allocation of indirect spending, it can support the performance of each unit in service to the community. Empowerment and alignment of regional expenditure allocation for improving basic infrastructure and services is important for the development of the region in terms of autonomy. Performance indicators that show the achievement of better output and quality of service can support various social and economic activities of the community. Thus, the results, benefits, and 
impacts can be felt directly or indirectly by the greatest number of people which can lead to an increase in overall welfare. To that end, our findings are consistent with Gonschorek et al. (2018), Kis-Katos and Sjahrir (2017), Lewis (2010, 2017) and Sanogo (2019).

The estimation results show that per capita income, as a reflection of people's purchasing power, has no influence on the HDI. This finding implies that the per capita income of people in regencies/cities in Papua has not been able to increase HDI, partly because of the relatively small income of the community. This condition results in a greater government allocation to meet the primary needs of the community, so that expenditures on education and health are relatively limited. As a result, the quality of HDI receives little attention or is neglected. The increasing role of the community in the midst of government budget constraints is helpful in supporting government programs to increase the HDI. Although regional expenditure in the form of direct and indirect expenditure tends to increase every year, it remains inadequate to meet both private and public community needs (Gonschorek et al., 2018).

\section{Conclusion}

This study has hown that capital expenditures especially direct expenditures have positive impact on human development index (HDI) in Papua province. The positive impact of capital expenditures on human HDI has been enhanced and facilitated by the local government financial resources provided by DPRD which are special allocation funds and special autonomy funds. Such special allocation funds and special autonomy funds are provided to finance education and health deficiencies HDI should be higher when DPRD financial resources increase to fund the operationalization of education and health sectors; increasing the outcome on Indonesian society. Government fiscal policies which govern the allocated funds and prioritize funded sectors strengthen the positive effect of capital expenditures on HDI. The higher funds provided and the higher priority of allocated funds for education and health sectors are the higher increase of HDI in Papua province. All in all, this study suggests that positive human development can take place in an era of autonomy, as long as regional governments make capital expenditures which benefit the community widely. In an era of fiscal decentralization in Indonesia, regions are required to carry out their functions effectively and efficiently, especially in regards to programs/activities aimed at increasing the HDI. Therefore, the regional governments are expected to be able to increase their fiscal capacity and to increase their allocations for programs and activities which may lead to an increase of HDI. Regional governments are expected to not only pursue economic improvement, but also show the strong political will be needed to create a high HDI by increasing human resources so that they can improve the welfare of the community. Regional government is expected to explore and to utilize potential and regional economic sectors that can increase the source of tax revenue so that they can fund all regional government activities independently and not depend on the transfer of funds from the central government. They are expected to take advantage of funds originating from per capita taxes to develop human resources, build public infrastructure, and support other facilities that are needed by the community. A feasibility study and analysis of public investment must always be done before the construction of public facilities and infrastructure, so that all involved are assured the project will meet the stated objectives. Officers who are assigned to manage the operation of the built facilities and infrastructure must be consulted, so that the construction of public facilities can be achieved.

\section{References}

Achsani, N. A., Tambunan, M., \& Mulyo, S. A. (2012). Impact of fiscal policy on the agricultural development in an emerging economy: Case study from the South Sulawesi, Indonesia. International Research Journal of Finance and Economics, 96, 101-112.

Amalia, F.R., \& dan Purbadharmaja, I.B.P. (2014). Pengaruh Kemandirian Keuangan Daerah Dan Keserasian Alokasi Belanja Terhadap Indeks Pembangunan Manusia. E-Jurnal Ekonomi Pembangunan Universitas Udayana, 3(6).

Ananta, A. (1986), Masalah dan Prospek Ekonomi Indonesia 1986/1987 dalam (ED) Moh. Arsyad Anwar, UI Press, Jakarta, Indonesia. 
Arndt, H. W. (1981). Economic development: a semantic history. Economic Development and Cultural Change, 29(3), 457-466.

Astri, M., Nikensari, S. I., \& Kuncara, H. (2013). Pengaruh Pengeluaran Pemerintah Daerah pada Sektor Pendidikan dan Kesehata Terhadap Indeks Pembangunan Manusia di Indonesia. Jurnal Pendidikan Ekonomi dan Bisnis (JPEB), 1(1), 77-102.

Bhakti, N. A., Istiqomah, I., \& Suprapto, S. (2018). Analisis Faktor-faktor yang Mempengaruhi Indeks Pembangunan Manusia di Indonesia Periode 2008-2012. EKUITAS: Jurnal Ekonomi dan Keuangan, 18(4), 542-469.

Booth, A. (2003). Decentralisation and poverty alleviation in Indonesia. Environment and Planning C: Government and Policy, 21(2), 181-202.

Badan Pusat Statistik (2009). Statistik Indonesia. Jakarta Pusat: Badan Pusat Statistik.

Badan Pusat Statistik (2015). Statistik Penduduk Lanjut Usia 2014, Jakarta: Badan Pusat Statistik.

Brata, A. G. (2004). Analisis Hubungan Imbal Balik Antara Pembangunan Manusia dan Kinerja Ekonomi Daerah Tingkat II di Indonesia. Lembaga Penelitian - Universitas Atma Jaya, Yogyakarta.

Cohen, P. T., \& Purcal, J. T. (1989). The political economy of primary health care in Southeast Asia. Australian Development Studies Network, ASEAN Training Centre for Primary Health Care Development.

Feoli, E., Vuerich, L. G., \& Woldu, Z. (2002). Processes of environmental degradation and opportunities for rehabilitation in Adwa, Northern Ethiopia. Landscape ecology, 17(4), 315-325.

Fhino A.C., \& dan Priyo H. A. (2009). Hubungan Antara Dana Alokasi Umum, Belanja Modal Dan Kualitas Pembangunan Manusia, Naskah lengkap, The 3rd National Conference UKWMS" Surabaya, October 10th 2009.

Firman, T. (2003). Potential impacts of Indonesia's fiscal decentralisation reform on urban and regional development: Towards a new pattern of spatial disparity. Space and Polity, 7(3), 247-271

Fox, M. A., \& Hamilton, R. T. (1994). Ownership and diversification: Agency theory or stewardship theory. Journal of Management Studies, 31(1), 69-81.

Gonschorek, G. J., Schulze, G. G., \& Sjahrir, B. S. (2018). To the ones in need or the ones you need? The political economy of central discretionary grants- empirical evidence from Indonesia. European Journal of Political Economy, 54, 240-260.

Gozali, A. (2001), Manajemen Otonomi Daerah : Birokrasi Ekonomi Sosial. Pattimura, L. (Ed.) Pustaka LSKPI, Jakarta, Indonesia.

Hair Jr, J. F., Hult, G. T. M., Ringle, C., \& Sarstedt, M. (2016). A primer on partial least squares structural equation modeling (PLS-SEM). Sage publications

Halim, A. (2007). Akuntasi Sektor Publik: Akuntansi Keuangan Daerah, Salemba Empat, Jakarta, Indonesia.

Hofman, B., \& Guerra, S. C. (2007). Ensuring inter-regional equity and poverty reduction. In Fiscal Equalization (pp. 31-59). Springer, Boston, MA.

Jensen, M. C., \& Meckling, W. H. (1976). Theory of the firm: Managerial behavior, agency costs and ownership structure. Journal of financial economics, 3(4), 305-360.

Johnston, B. F., \& Mellor, J. W. (1961). The role of agriculture in economic development. The American Economic Review, 51(4), 566-593.

Kis-Katos, K., \& Sjahrir, B. S. (2017). The impact of fiscal and political decentralization on local public investment in Indonesia. Journal of Comparative Economics, 45(2), 344-365.

Lerner, D. (1958). The Passing of Traditional Society: Modernizing the Middle East. The Free Press, New York, NY.

Lewis, B. D. (2010). Indonesian decentralization: Accountability deferred. International Journal of Public Administration, 33(12-13), 648-657.

Lewis, B. D. (2017). Local government spending and service delivery in Indonesia: the perverse effects of substantial fiscal resources. Regional Studies, 51(11), 1695-1707.

Marmot, M. (2005). Social determinants of health inequalities. The lancet, 365(9464), 1099-1104.

Moreno-Enguix, M. D. R., \& Lorente Bayona, L. V. (2017). Factors affecting public expenditure efficiency in developed countries. Politics \& Policy, 45(1), 105-143. 
Musgrave, R. A. (1956). A multiple theory of budget determination. FinanzArchiv/Public Finance Analysis, (H. 3), 333-343.

Myrdal, G. (1974). What is development?. Journal of Economic Issues, 8(4), 729-736.

Nurmainah, S. (2013). Analisis Pengaruh Belanja Modal Pemerintah Daerah, Tenaga Kerja Terserap dan Indeks Pembangunan Manusia Terhadap Pertumbuhan Ekonomi dan Kemiskinan (Studi Kasus 35 Kabupaten/Kota di Provinsi Jawa Tengah). Jurnal Bisnis Dan Ekonomi, 20(2), 1412-3126.

Prasetyo, A. D., Mulyono, N. B., \& Nugroho, L. I. (2018). Local governments' expenditures efficiencies and determinants: the case of Indonesia. International Journal of Trade and Global Markets, 11(3), $160-177$.

Ranis, G., \& dan F. Stewart. (2006). Economic Growth and Human Development in Latin America. Cepal No. 78. The UN Economic Commission for Latin America and the Caribbean (ECLAC).

Rogers, E.M. (1995). Diffusion of Innovations: Fourth Edition. The Free Press, New York, NY.

Sahrah, A. (2007). Memberdayakan Sumber Daya Manusia Untuk Meningkatkan Kualitas Bangsa, Pidato Dies Natalis Unwama ke XXI, Yogyakarta.

Sandri, N. K., Putri, I.G dan Dwirandra, A.A.N.B. (2016), Kemampuan Alokasi Belanja Modal Memoderasi Pengaruh Kinerja Keuangan Daerah Pada Indeks Pembangunan Manusia. Jurnal Buletin Studi Ekonomi, 21(1),

Sanogo, T. (2019). Does fiscal decentralization enhance citizens' access to public services and reduce poverty? Evidence from Côte d'Ivoire municipalities in a conflict setting. World Development, 113, 204-221

Sasana, H. (2009). Peran desentralisasi fiskal terhadap kinerja ekonomi di kabupaten/kota provinsi Jawa Tengah. Jurnal Ekonomi Pembangunan: Kajian Masalah Ekonomi dan Pembangunan, 10(1), 103124.

Sasana, H. (2016). Pengaruh Belanja Pemerintah Daerah Dan Pendapatan Perkapita Terhadap Indeks Pembangunan Manusia (Studi Kasus Di Kabupaten/Kota Provinsi Jawa Tengah). Media Ekonomi dan Manajemen, 25(1).

Sinulingga, B. (2008). Analisis Pengaruh Distribusi APBD Terhadap Indeks Pembangunan Manusia. Jurnal Ilmu Administrasi Negara, 1(1), 106-120.

Sukirno, S. (2000). Makro ekonomi Modern:Perkembangan Pemikiran Dari Klasik Hingga Keynesian Baru. PT Raja Grafindo Pustaka, Jakarta, Indonesia.

Sularso, H., \& Restianto, Y. E. (2012). Pengaruh kinerja keuangan terhadap alokasi belanja modal dan pertumbuhan ekonomi kabupaten/kota di Jawa Tengah. Media Riset Akuntansi, 1(2), 109-124.

Todaro, M.P. (2003). Pembangunan Ekonomi, Erlangga, Jakarta, Indonesia.

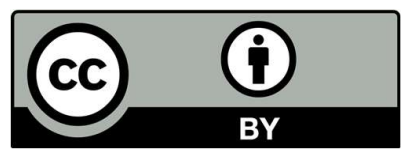

(C) 2019 by the authors; licensee Growing Science, Canada. This is an open access article distributed under the terms and conditions of the Creative Commons Attribution (CCBY) license (http://creativecommons.org/licenses/by/4.0/). 